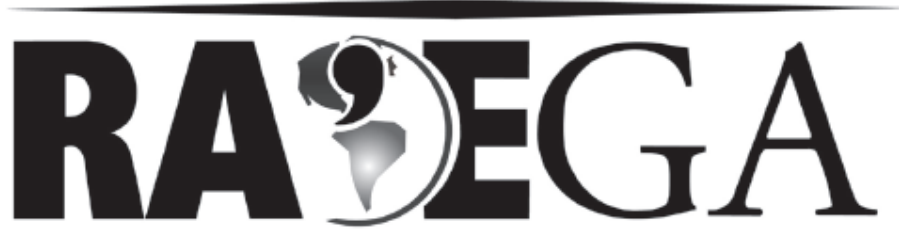

O ESPAÇO GEOGRÁFICO EM ANÁLISE

\title{
O OLHAR DOS EMPRESÁRIOS DO RAMO DE CONFECÇÃO DA REGIÃO SUDOESTE DO PARANÁ SOBRE AS FONTES DE VANTAGENS COMPETITIVAS ENCONTRADAS NO LOCAL PARA O DESENVOLVIMENTO DO SETOR
}

\section{THE POINT OF VIEW FROM GARMENT INDUSTRY BUSINESSMAN LOCATED IN SOUWEST PARANÁ STATE CONCERNING TO THE COMPETITIVE}

\author{
Sonia Mar dos Santos Migliorini ${ }^{1}$ \\ Luís Lopes Diniz Filho²
}

\section{RESUMO}

O presente artigo tem como objetivo identificar as fontes de vantagens competitivas que a indústria de confecção encontra na região Sudoeste do Paraná para o seu desenvolvimento e averiguar a importância dada pelos entrevistados a estas vantagens. A metodologia utilizada para desenvolver a pesquisa foi preenchimento de questionário de pesquisa, com questões qualitativas e quantitativas, pelos proprietários da indústria de confecção, desenvolvidos com base na teoria da competitividade de Michael Porter, a Vantagem Competitiva das Nações, e de Luciano Coutinho e João Ferraz, Estudo da Competitividade da Indústria Brasileira: competitividade da indústria do vestuário; análise e tabulação dos dados levantados na pesquisa de campo.

\footnotetext{
1 Doutoranda no Programa de Pós-Graduação em Geografia da Universidade Federal do Paraná; Realizou Doutorado Sanduíche pela Universidade de Paris IV - Sorbonne. Curitiba, Paraná, Brasil (snmigliorini@gmail.com).

2 Doutor em Geografia Humana pela Universidade de São Paulo - USP; Professor Adjunto do Departamento de Geografia da Universidade Federal do Paraná. Curitiba, Paraná, Brasil (diniz.ufpr@gmail.com).
} 
A teoria da competitividade, por abranger um conjunto de elementos que atinge desde fatores externos ao país onde a indústria está localizada, perpassando pelos determinantes da competitividade em nível nacional, estadual, regional, alcançando os fatores internos às próprias indústrias, possibilitou a identificação dos fatores que motivaram a implantação e desenvolvimento da indústria de confecção na Região de estudo. Como conclusão apresenta-se um conjunto de fatores considerados pelos empresários da indústria de confecção como as maiores vantagens competitivas encontradas na região Sudoeste para o desenvolvimento desta indústria.

Palavras-Chave: indústria de confecção; vantagens competitivas; região Sudoeste.

\section{ABSTRACT}

This article aims to identify sources of competitive advantages which the construction industry in the Southwest Meso region of Paraná has available for development and to determine the importance of these advantages as seen by respondents. The methodology used to develop the research was completion of a questionnaire by the owners of the construction industries, with qualitative and quantitative questions, geared towards identification of sources of competitive advantage in this industry in the region of study, as well as analysis and tabulation of data collected in field research. The theory of the competitiveness, by enclosing a set of elements that reaches since external factors to the country where the industry is located, going throughout determinative competitiveness factors in national, state, regional level, up to the internal factors to the proper industries, made possible the identification of factors that had motivated the implantation and development of the industry of clothes in the Region of study. Concluding with presenting a set of factors considered by entrepreneurs in the construction industry as the biggest competitive advantages found in the Southwest Mesor region for the development of this industry.

Key-words: industry; construction; competitive advantage; Southwest region; supplier and consumer market.

\section{INTRODUÇÃO}

A indústria de confecção, por exigir pouco nível tecnológico e pequeno investimento de capital, é um dos setores que mais cedo se desenvolveu no Brasil e, por conta desta característica, em muitas regiões, assim como ocorreu no início da industrialização do Brasil, essa indústria é a precursora do processo de industrialização. Nesse contexto está a região Sudoeste do Paraná, área de estudo desta pesquisa, onde a indústria de confecção foi uma 
das primeiras a se desenvolver e atualmente é um dos setores industriais com maior importância econômica da Região em termos de geração de emprego e renda. Nos últimos anos, especialmente a partir da década de 1990, a indústria de confecção regional vem crescendo aceleradamente tanto em número de unidades industriais, com um crescimento de $304 \%$ entre 1990 e 2007, quanto em escala de produção e comercialização.

Este artigo tem como objetivo identificar as vantagens competitivas encontradas pela indústria de confecção na região Sudoeste do Paraná e averiguar a importância dada pelos entrevistados a estas vantagens para a implantação e desenvolvimento de sua indústria. A metodologia utilizada para desenvolver a pesquisa foi o preenchimento de questionário de pesquisa, com questões qualitativas e quantitativas, pelos proprietários das indústrias de confecção, orientado para a identificação das fontes das vantagens competitivas desta indústria na Região de estudo, com base na teoria da competitividade de Michael Porter, a Vantagem Competitiva das Nações, e de Luciano Coutinho e João Ferraz, Estudo da Competitividade da Indústria Brasileira: competitividade da indústria do vestuário. Esta teoria, por meio de sua análise ampla e detalhada sobre os condicionantes da competitividade das empresas, permite identificar tanto os fatores que influenciam no movimento da indústria no espaço geográfico, em busca de maiores vantagens competitivas, quanto às vantagens competitivas existentes em um determinado país ou região que determinam a implantação e o desenvolvimento de um setor industrial ou empresarial, como é o caso do setor de confecção da região Sudoeste do Paraná.

\section{COMPETITIVIDADE SISTÊMICA: CONCEITOS E MODELOS}

Nesta seção abordam-se conceitos e modelos de competitividade sistêmica e sua aplicabilidade para o estudo da indústria de confecção. Mais especificamente, o propósito desta discussão teórica é analisar os fatores sistêmicos que influenciam na competitividade da indústria instalada em 
determinado local ou região, especialmente da indústria de confecção, que é o assunto pertinente a este artigo. Esta seção visa, também, buscar subsídios teóricos que ajudem a apreender os fatores determinantes da implantação da indústria de confecção na região Sudoeste do Paraná, fornecendo base à pesquisa de campo.

Desde a reestruturação produtiva, nas décadas de 70 e 80, o tema da competitividade tornou-se bastante freqüente no debate econômico. Com as transformações econômicas dos anos 80 e 90, a partir da globalização econômica, paulatinamente, a tradicional visão de competitividade foi suplantada à medida que foram ampliando-se os elementos constitutivos da capacidade de competir das nações.

Segundo Porter (1989, p.10), há duas estratégias competitivas básicas para uma indústria: o enfoque de custos e a diferenciação do produto. A vantagem competitiva de qualquer uma dessas duas estratégias traduz-se em produtividade superior à dos concorrentes. Uma indústria, segundo o referido autor, para obter sucesso deve buscar sua vantagem competitiva em uma dessas estratégias competitivas genéricas e relacioná-la com as estratégias de seus concorrentes.

Porter (1998, p.143), após ter sistematizado os estudos de várias indústrias de dez nações diferentes, classificou quatro atributos que, individualmente ou como um sistema, constitui o diamante ${ }^{3}$ da vantagem competitiva de uma nação ou região, e acrescentou a esses mais dois fatores que afetam a competitividade das indústrias, tanto de forma negativa quanto positivamente: o papel do acaso e o papel do governo. A figura 01 apresenta o sistema completo desenvolvido por Porter que pode ser melhor compreendido através das descrições a respeito de cada um dos fatores. Segundo o próprio autor, esses atributos podem ser facilmente aplicados em unidades políticas ou geográficas menores que um país, como um estado, uma região ou uma cidade.

3 "Diamante" é a expressão usada por Porter para referir-se aos determinantes como um sistema (1989, p.88). 


\section{Figura 01 - Determinantes da Vantagem Nacional: o sistema completo}

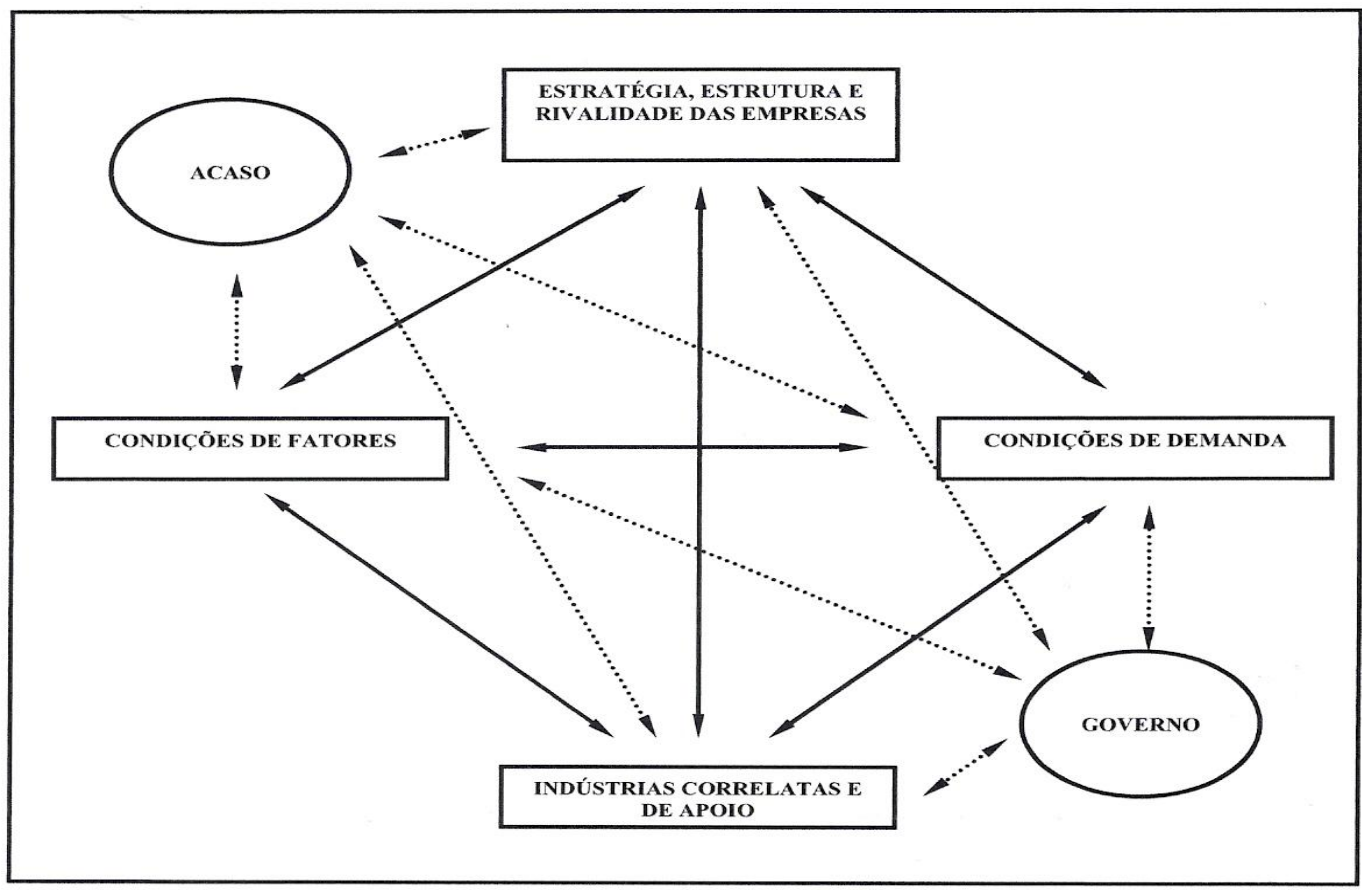

Fonte: PORTER, 1989, p.146.

Nota: As setas com linhas pontilhadas representam a influencia de um fator sobre o outro nem sempre explícita, mas nem por isso deixa de ser relevante no desempenho competitivo das indústrias.

As condições de fatores apresentado na figura 01 se refere aos insumos necessários para a indústria competir. Engloba desde infraestruturas básicas como transporte, energia, telecomunicações, assistência médica, incluindo, ainda, disponibilidade de casa, instituições culturais e os atrativos de um país que afetam a qualidade de vida, passando pela oferta de mão-de-obra habilitada; abundância, qualidade, disponibilidade e acessibilidade dos recursos naturais; abarcando, ainda, os centros de pesquisas universitários e os recursos de capital que se resumem na capacidade econômica e garantias que um país dispõe para o financiamento e investimento nas indústrias. 
Já as condições de demanda, segundo o referido autor, determinam a natureza da demanda interna para os produtos e serviços de um país. Ou seja, determina o rumo e o caráter de melhoria e inovação pelas indústrias do país; a competitividade das indústrias pode ser afetada até mesmo pelos valores culturais e simbólicos atribuídos a um determinado produto. Nesse determinante há três atributos gerais significativos: composição da demanda interna - natureza das necessidades do comprador - tamanho e padrão de crescimento e mecanismos pelos quais a preferência interna é transmitida aos mercados estrangeiros.

As indústrias correlatas e de apoio, refere-se à presença, no país, de indústrias fornecedoras e de apoio $^{4}$ que sejam internacionalmente competitivas; estas podem proporcionar insumos mais eficazes em termos de custos e de modo rápido, antecipado e até preferencial. Nesse atributo, a vantagem competitiva surge da estreita relação entre os fornecedores mundialmente competitivos e a indústria. Através dos fornecedores as indústrias têm acesso fácil às informações, às novas idéias, ao conhecimento e às inovações dos fornecedores. O intercâmbio de pesquisa e desenvolvimento e a solução conjunta dos problemas levam a resultados mais eficientes. Há uma tendência de os fornecedores transmitirem informações de indústrias para indústrias, acelerando, através desse processo, o ritmo de inovação dentro de toda a indústria nacional.

A estratégia, estrutura e rivalidade das empresas, são as condições que, dentro do país, estabelecem a maneira pelas quais as indústrias são criadas, organizadas e gerenciadas bem como a natureza da rivalidade interna. Ou seja, é o contexto no qual as firmas são criadas como: condições econômicas, institucionais, culturais e jurídicas de um país bem como a rivalidade das empresas. A rivalidade interna das indústrias cria pressões sobre essas para que melhorem e inovem. Os rivais locais pressionam-se mutuamente para melhorar a qualidade dos produtos e serviços, reduzir custos, criar novos

\footnotetext{
${ }^{4}$ Porter define indústrias de apoio como "aquelas em que empresas podem partilhar atividades na cadeia de valores através das indústrias (por exemplo, canais de distribuição, desenvolvimento de tecnologia) ou transferir conhecimentos protegidos pelo direito de propriedade de uma indústria para outra" (1989, p.150).
} 
produtos e processos. O sucesso de uma rival indica aos outros que o avanço é possível.

Já ao acaso são atribuídos aqueles acontecimentos puramente casuais, fortuitos, que pouco tem a ver com as circunstâncias de um país e que, em grande parte, estão fora do alcance das indústrias e até do governo nacional, mas que podem prejudicar ou beneficiar o desempenho das indústrias, tais como as decisões políticas de governos estrangeiros, guerras, rupturas tecnológicas - biotecnologia, microeletrônicas -, significativas mudanças nas taxas de câmbio, choque do petróleo.

Ao governo, na concepção de Porter, cabe o papel de influenciar os quatros determinantes, através das políticas nacionais. O governo pode influenciar e ser influenciado por cada um dos quatro determinantes, positiva ou negativamente: as condições de fatores são afetadas por meio de subsídios, políticas para o mercado de capital, políticas educacionais, conhecimentos científicos básicos e informações econômicas ou infraestrutura; sobre as condições de demanda, as políticas governamentais têm-se centralizado tradicionalmente na influência sobre a quantidade geral de demanda interna, através do dispêndio governamental, ou na manipulação da disponibilidade ou custo de crédito. O efeito mais direto do governo sobre as condições de demanda é através da sua atuação como comprador de mercadorias e serviços. Já as indústrias correlatas e de apoio são beneficiadas através das mesmas políticas governamentais que fortalecem a vantagem competitiva das indústrias em geral. A política governamental também influi na estrutura da estratégia das indústrias e na rivalidade através de recursos como regulamentação do mercado de capital, política fiscal e leis antitrustes.

Na concepção de Porter, o papel do governo é bastante limitado em sua contribuição para criar vantagem competitiva. Para o autor, embora o governo tenha importante influência sobre a vantagem competitiva nacional, seu papel é parcial e, segundo ele, a política governamental falhará se for a única fonte de vantagem competitiva nacional. Dessa forma, cabe ao governo apressar ou aumentar as probabilidades de obter vantagem competitiva, mas não possui o poder de criá-la. 
Como é possível observar, essa abordagem teórica engloba as mais variadas dimensões da competitividade, abrangendo desde os fatores locais de um determinado lugar, como um país ou uma região, tais como oferta de mãode-obra e infraestrutura econômica, até fatores internacionais, se constituído em uma teoria de grande amplitude e passível de ser utilizada para identificar as fontes de vantagens competitivas dos mais diversos setores da economia, como o setor de confecção, por exemplo, localizado em um dado país ou região.

Uma segunda abordagem sobre a competitividade sistêmica é o Estudo da Competitividade da Indústria Brasileira (ECIB), desenvolvido no Brasil na década de 1990, tendo como coordenadores Luciano G. Coutinho, do Instituto de Economia da UNICAMP, e João Carlos Ferraz, do Instituto de Economia Industrial da UFRJ. Esta abordagem inclui como fator importante para a competitividade o diálogo direto entre os atores sociais: empresários, trabalhadores, autoridades governamentais, acadêmicos e servidores públicos.

Coutinho e Ferraz (1993a, p.10), afirmam que a noção de competitividade sistêmica representa um modo de expressar que o desempenho empresarial depende e é também resultado de fatores situados além do âmbito das indústrias e das estruturas industriais das quais as indústrias fazem parte, sendo influenciada, também, pelos fatores macroeconômicos, infraestrutura, sistema político-institucional e características socioeconômicas dos mercados nacionais. Para os autores a "competitividade pode ser vista como a produtividade das empresas ligadas à capacidade dos governos, ao comportamento da sociedade e aos recursos naturais e construídos, e aferidos por indicadores nacionais e internacionais, permitindo conquistar e assegurar fatias do mercado" (1993c, p.11). Conforme os referidos autores, o motor que impulsiona o desenvolvimento é a inovação, e esse fator possui grande peso na sobrevivência das indústrias em um ambiente competitivo. A reestruturação produtiva depende fortemente da incorporação contínua dos conhecimentos em produtos e processos. Os determinantes da competitividade sistêmica foram subdivididos, no ECIB, em três grupos, conforme mostra a figura 02. 


\section{Figura 02 - Fatores Determinantes da Competitividade da Indústria (Empresa ou Nação).}

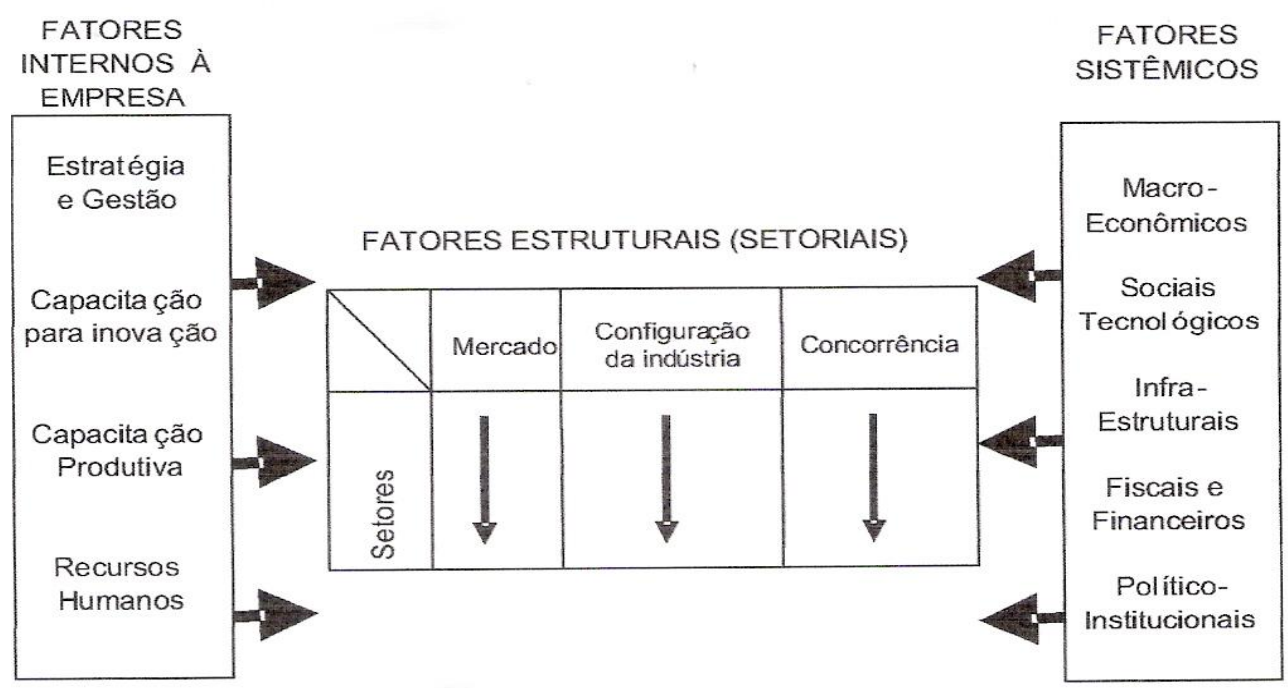

Fonte: Coutinho e Ferraz, 1993c, p.21.

Fatores Internos à Empresa - são fatores que estão sob as decisões das empresas ou indústrias. Através da eficiência administrativa, as indústrias diferenciam-se de seus competidores e criam vantagens competitivas. Incluem os estoques de recursos acumulados pelas indústrias, as vantagens competitivas que possuem e a sua capacidade de ampliá-las, tais como a capacitação tecnológica e produtiva; a qualidade e produtividade dos recursos humanos; o conhecimento do mercado e a capacidade de se adequar às suas especificidades; as relações privilegiadas entre fornecedores e clientes e os serviços de pós-venda, entre outros.

Fatores Estruturais - são aqueles fatores que, mesmo não sendo totalmente controlados pela indústria, estão parcialmente sob a sua área de influência e define o ambiente competitivo enfrentado pelas indústrias. Este atributo engloba as características dos mercados consumidores referente à distribuição geográfica, às faixas de renda, oportunidades de acesso aos mercados internacionais; à configuração da indústria, como grau de concentração, escala de operação, atributos dos insumos, potencialidade de alianças com fornecedores, usuários e concorrentes, origem e direção do 
progresso técnico; a natureza da concorrência, meio ambiente e competidores, sistema fiscal-tributário, práticas de importação e exportação.

Fatores Sistêmicos - correspondem aos fatores externos às indústrias, mas também afetam as características do ambiente competitivo e podem ser relevantes nas vantagens competitivas que as indústrias de um país possuem ou deixam de possuir em relações às suas rivais na competição internacional. Esses fatores podem ser de natureza: macroeconômicas (taxas de câmbio, oferta de crédito e taxas de juros); político-institucionais (políticas tributária e tarifária); regulatórios (políticas de proteção à propriedade industrial, preservação ambiental, políticas de defesa da concorrência e proteção ao consumidor); infraestrutura (serviços tecnológicos, energia, transporte, telecomunicação); sociais (qualificação da mão-de-obra, políticas de educação e formação de recursos humanos, legislação trabalhista, seguridade social e grau de exigência dos consumidores); fatores referentes à dimensão regional (que engloba os aspectos relativos à distribuição espacial da produção); e, por fim, fatores de escala internacional (tendências do comércio mundial, fluxos internacional de capital, de investimento de risco e de tecnologia, políticas do comércio exterior e acordos internacionais).

Do mesmo modo que a teoria de Porter, a teoria desenvolvida por Coutinho e Ferraz também abrange uma grande variedade de fatores que tem influência sobre a competitividade da indústria, tratando desde fatores internos à ela até fatores externos ao país onde a mesma está localizada. Desta forma, pode se afirmar, que os dois modelos de competitividade sistêmica aqui apresentados compreendem a competitividade como resultado da atuação conjunta de forças de mercado e forças que não estão relacionadas ao mercado e estão fora do alcance das indústrias, mas mesmo assim são fundamentais para o sucesso competitivo destas. Além disto, estas teorias são passiveis de serem aplicadas em tamanhos de unidades geográficas ou administrativas diversas.

A análise do conjunto de fatores da competitividade sistêmica permite que se avaliem todos os aspectos relevantes para o desenvolvimento econômico das nações através de suas indústrias, podendo-se, também, 
identificar os pontos fortes e fracos de determinado setor econômico, a exemplo do setor de confecção. É possível ainda, identificar as vantagens competitivas ofertadas por uma determinada região para o desenvolvimento de um setor econômico, a exemplo da região Sudoeste do Paraná.

De uma maneira geral, a diferença fundamental entre as duas teorias apresentadas está na maneira de conceber as políticas públicas como um dos fatores determinantes para a competitividade das indústrias ou não. O modelo do ECIB da ênfase maior às políticas públicas como determinantes das vantagens das indústrias, enquanto o modelo de competitividade desenvolvido por Porter restringe o papel do governo apenas a influenciar os quatro atributos que determinam a competitividade em seu modelo.

O levantamento dos fatores condicionantes de competitividade, por meio das teorias apresentadas, podem auxiliar no desenvolvimento de políticas públicas e estratégias empresariais para o fortalecimento econômico, em escala regional, nacional ou internacional. Desta forma, Diniz Filho e Vicentini afirmam que "o conceito de competitividade sistêmica apresenta necessariamente uma dimensão geográfica, na medida em que trata das interrelações entre inúmeros fatores de produção que possuem expressão espacial e que ocorre em escalas variadas, que vão do regional ao global" (2004, p. 113). Assim, a teoria da competitividade sistêmica foi fundamental para identificar, na região Sudoeste, os fatores que condicionaram a implantação e o desenvolvimento da indústria de confecções bem como sua competitividade atual.

$\mathrm{Na}$ próxima seção, analisa-se a competitividade da indústria de confecção nacional, a partir dos modelos de competitividade sistêmicas apresentados acima, especialmente aquele desenvolvido por Coutinho e Ferraz para o Estudo da Competitividade da Indústria Brasileira. 


\section{COMPETITIVIDADE DA INDÚSTRIA DE CONFECÇÃO BRASILEIRA}

A indústria de confecção ${ }^{5}$ brasileira não difere das outras indústrias quanto aos fatores condicionantes de competitividade. $\mathrm{Na}$ estrutura da indústria de confecção brasileira o setor registra forte heterogeneidade tanto em nível das plantas industriais - em sua maior parte é resultante das características do mercado (mesmo as indústrias produzindo produtos semelhantes podem se utilizar de técnicas produtivas distintas) -, quanto em nível de diversidade de itens fabricados pelas indústrias (pode ir de uma simples camiseta à ternos e roupas femininas sofisticadas). Essa heterogeneidade da estrutura da indústria de confecção brasileira Coutinho e Ferraz atribuem à própria heterogeneidade do mercado consumidor, em que convivem diferentes segmentos de níveis de renda, padrões de informação e exigência.

A estrutura da indústria de confecção brasileira, conforme dados da ABRAVEST - Associação Brasileira do Vestuário - é composta de um número bastante elevado de unidades industriais, 22.112 em 2010, constituindo-se em torno de $96 \%$ delas de micro, pequenas e médias indústrias. Isso se deve, segundo a fonte citada, fundamentalmente, à inexistência de barreiras técnicas significativas à entrada de novas indústrias no setor, no que se refere à escala de produção, tecnologia de processo ou produto, volume de recursos necessários ou treinamento da mão-de-obra.

A heterogeneidade da indústria de confecção brasileira, conforme Coutinho e Ferraz (1993b), acentua-se ainda mais entre as indústrias de pequeno e médio porte. Nesses níveis, existe grande número de indústrias tecnologicamente defasadas que estão voltadas prioritariamente ao mercado interno, as quais se munem de estratégias de competição baseada em redução de custos. Outro grupo de indústrias, parcialmente modernizadas, na maioria dos casos, voltam-se para nichos do mercado interno de alta renda. Essas adotam estratégias competitivas de diferenciação do produto e enfatizam o controle de qualidade.

\footnotetext{
${ }^{5}$ Nesta pesquisa quando há referência à indústria de confecção deve ficar claro que se trata da indústria de confecção de artigos do vestuário, código 18 da Classificação Nacional de Atividade Econômica (CNAE), grupo 181.
} 
Conforme Coutinho e Ferraz (1993b, p.6), as grandes indústrias como buscam constantemente, como estratégia empresarial, a modernização e ganhos de produtividade, em sua maioria são indústrias atualizadas tecnologicamente e organizacionalmente. Tais indústrias têm, no mercado exterior, esquemas bem estruturados de comercialização e venda de seus produtos, e são as responsáveis pelas exportações brasileiras. Uma das maiores indústrias desse setor, no início da década de 1990, conforme a referida fonte, exportava $35 \%$ de sua produção.

\begin{abstract}
A conjuntura de pouca exposição à competição externa, tanto pelo lado de exportação como de importações, com a própria heterogeneidade, em todos os sentidos - renda, situação geográfica, formação cultural -, do mercado consumidor brasileiro, acabou por conformar uma estrutura industrial ainda mais heterogênea que aquela que normalmente caracteriza o setor de confecções internacional. Por esse motivo, são encontradas plantas com distintos níveis de capacitação, desempenho e produtividade nos diversos segmentos do setor. (COUTINHO E FERRAZ, 1993b, p.6).
\end{abstract}

Quanto aos fatores determinantes da competitividade da indústria de confecção, o estudo do ECIB (1993b) segue o modelo que desenvolveu para o estudo da indústria brasileira como um todo; e está subdividido em três grupos de condicionantes da competitividade: fatores internos à empresa; fatores de natureza estrutural - pertinentes aos setores e complexos industriais -; e fatores de natureza sistêmica, conforme exposto na figura 02.

Nos fatores internos à empresa, ou fatores empresariais, o referido estudo constatou que, no início da década de 1990, a indústria de confecção brasileira possuía uma fraca adoção de estratégias empresariais de capacitação tecnológica e gerencial. Praticamente inexistiam processos de integração e cooperação entre as indústrias; havia grande disparidade tecnológica entre elas; tecnicamente, era possível produzir o mesmo produto com combinação de intensidade diversa de capital e trabalho, fazendo com que fossem atingidos os custos comparativos; a utilização de técnicas organizacionais modernas ainda era restrita no setor, sendo poucas as indústrias que utilizavam técnicas de organização como círculos de controle de qualidade, just-in-time - que tem como princípio o melhor aproveitamento possível do tempo de produção -, Kanban - controla a reposição de estoques por meio de senhas -, e Grupos de trabalhos, que tendem a melhorar o 
ambiente de trabalho, posto que a diminuição dos níveis hierárquicos gera maior envolvimento dos trabalhadores no processo de produção; o treinamento da mão-de-obra é uma prática pouco utilizada na indústria. A maioria das indústrias não realizava qualquer treinamento de seus funcionários, em todos os níveis hierárquicos; as pequenas e médias são as que menos realizavam (e realizam ainda) treinamento direto de sua mão-de-obra e, ainda, utilizavam pouco, em comparação com as grandes indústrias, as instituições de apoio para a formação de recursos humanos.

Nos fatores estruturais o estudo do ECIB (1993b, p.45), apontou a heterogeneidade da indústria de confecção como responsável pelos diferentes desempenhos e inserções competitivas. Apenas poucas indústrias conseguiram reunir as capacitações necessárias para uma penetração competitiva no mercado internacional, e essas são, em geral, grandes indústrias com boa atualização tecnológica e organizacional. A subcontratação de indústrias menores para a prestação de serviços, ou seja, a terceirização de algumas fases da produção ou mesmo a subcontratação total de certas linhas de produtos, era, no início da década de 1990, uma das principais estratégias competitivas desse setor. No Brasil, essa prática tem visado apenas à redução de custos diretos, sem maior preocupação com a qualidade do produto e, na maioria das vezes, visa, principalmente, contornar obrigações tributárias e trabalhistas. A concentração geográfica da indústria em uma mesma região sugere a oportunidade de formação de pólos de modernização que, ao mesmo tempo, pode servir para estreitar relações inter-indústrias e estimular a cooperação, como é o caso dos pólos de Vilar dos Teles (RJ) e o polo de Americana (SP).

A atuação das pequenas e médias indústrias em conjunto pode beneficiá-las na aquisição de equipamentos, compra de matérias-prima, centrais de acabamentos assim como facilita o acesso a equipes de consultores especializados, e podem ser favorecidas pelo apoio das instituições de pesquisa e informações.

A infraestrutura tecnológica, conforme o estudo do ECIB (1993b, p.45), é um fator chave na busca de competitividade pelas pequenas e médias 
indústrias. A oferta de tecnologia relacionada à pesquisa e desenvolvimento de matérias-prima e produtos, a prestação de serviços nas áreas de controle de qualidade e a formação de recursos humanos podem ocorrer através de empresas privadas ou instituições públicas, porém, há uma heterogeneidade na capacitação da oferta de serviços pelas instituições públicas, cuja avaliação é de uma capacitação mediana na prestação de serviços, enquanto os laboratórios mantidos pelas empresas multinacionais são considerados bem capacitados.

Entre os fatores sistêmicos que dificultavam 0 aumento da competitividade da indústria de confecção, no início da década de 1990, conforme o estudo do ECIB (1993b, p.46), encontrava-se a ausência de crescimento da renda nacional, uma vez que a produção era voltada fundamentalmente para mercado interno. Em vista da crescente intensidade de capital, a restrição à disponibilidade de crédito para as pequenas e médias indústrias a médio e longo prazo bem como seu custo são fatores desfavoráveis à competitividade do setor. Esse fator tende a acentuar a concentração da produção e a heterogeneidade tecnológica, já que a maioria dessas indústrias não tem acesso ao mercado internacional de crédito ou mesmo ao mercado doméstico de capitais.

Outro fator importante, que contribui negativamente para o aumento da competitividade do setor, é o sistema tributário com sua complexidade e abrangência. "Os impostos em cascata elevam os custos dos insumos, bens de capital e do produto final sem a oportunidade de serem desonerados nas exportações" (Idem, 1993b, p.47). A "guerra fiscal" entre as Unidades da Federação também se constitui num condicionante negativo para o aumento da competitividade do setor de confecção. Essa prática - que pode ser tanto a isenção do ICMS como a permissão para pagamento desses benefícios a prazos dilatados e sem correção dos débitos fiscais - introduz distorções ao incentivar relocalização industrial em condições de tratamento tributário instáveis.

A alta carga tributária sobre os encargos sociais é outro fator que desfavorece a competitividade do setor de confecção nacional, intensivo em 
mão-de-obra. Conforme dados da ABRAVEST (2006, p.10), chega a $117 \%$ do valor da folha de pagamento, sendo o percentual mais elevado entre os países produtores de confecção. Esse fator contribui sobremaneira para a estratégia de terceirização, ou informalização, adotado pela indústria nacional que, além de manter parcela importante da força de trabalho sem cobertura das obrigações sociais, estabelece uma concorrência predatória com as indústrias do setor formal. Indústrias que cumprem as obrigações sociais não conseguem competir em preços com as indústrias que atuam de modo informal, tornando quase que inevitável a participação daquelas no processo de informalização.

Em relação à questão internacional, o estudo do ECIB considera como principais fatores de competitividade sistêmica a proteção tarifária, condições de acesso aos principais mercados e o MERCOSUL.

O complexo têxtil, em 1990, foi o primeiro setor produtivo a antecipar a abertura comercial, alegando a ameaça ao plano antiinflacionário alimentado por itens de vestuário. Esse processo que liberalizou as importações não teve acompanhamento de mecanismos eficazes como apoio à capacitação tecnológica e redução da carga tributária para que as indústrias brasileiras conseguissem competir de igual para igual com as indústrias estrangeiras. Segundo o SEBRAE (2006, p.10), os juros elevados, o câmbio defasado e os impostos somaram uma contra-força que desalinhou a competitividade da indústria de confecção em relação à concorrência internacional. Como resultado da abertura da economia ao mercado externo, e o consequente crescimento das importações de artigos de confecções chineses e coreanos, que tomaram o mercado nacional, ocorreu o fechamento de centenas de unidades industriais de confecção e o encerramento de milhares de postos de trabalho.

No entanto, a abertura de mercado com redução de alíquotas para importação de confeccionados, conforme a ABRAVEST (2006, p.12), em alguns aspectos, foi considerado útil ao setor, levando-o ao seu reposicionamento de forma a competir com os concorrentes internacionais. A abertura do mercado estimulou a indústria nacional a adotar programas de melhoria de qualidade, de produtividade e de rápido atendimento. A vinda de 
produtos importados é também considerada pela ABRAVEST como fator positivo, estimulando a criatividade e a melhoria para o setor de confecção nacional, que vive basicamente da moda.

A abertura econômica do início dos anos de 1990, que provocou grande aumento das importações de produtos de confecções vindos da China e da Índia, principalmente, após meados da década, quando ocorreu o fortalecimento da moeda nacional, fez com que a indústria de confecção nacional passasse por forte reestruturação. Boa parte das indústrias que conseguiram sobreviver à abertura econômica passou por uma modernização. Segundo a Federação das Indústrias do Estado de Minas Gerais - FIEMG (2006, p.8), atualmente, as indústrias de confecção brasileiras passaram a investir mais em tecnologia, mão-de-obra qualificada, e aumento de produtividade, favorecendo a competição no mercado nacional e internacional.

Outro fator relevante para a competitividade da indústria nacional, conforme a FIEMG (2006, p.8), está na utilização de novas matérias-prima. O Brasil passou a ter acesso, com a abertura do mercado, aos mercados internacionais que fabricam tecidos modernos a preços competitivos. Além disso, segundo ABRAVEST (2006, p.12), na fase de desenho e corte grandes avanços foram obtidos com a introdução da tecnologia CAD/CAM, permitindo a economia de tecidos e ganhos de velocidades nas etapas de criação, especificação técnica das peças e modelagem. A subcontratação ou a terceirização da produção nas fases de costura e montagem das peças, segundo a referida fonte, também vem sendo usada como estratégia empresarial pelas indústrias nacionais, visando principalmente contornar obrigações sociais, ou seja, essa estratégia vem sendo confundida no Brasil com informalização da mão-de-obra para diminuir custos.

A criação de marcas próprias e a formação de pólos regionais, segundo a ABRAVEST (2010, p.15), atualmente, vêm sendo adotadas como estratégias empresariais para aumentar a competitividade da indústria nacional frente aos seus competidores nacionais e internacionais. Do mesmo modo, vem ocorrendo no Brasil uma relocalização espacial da indústria para regiões que 
ofereçam mão-de-obra abundante e de menor custo, carga tributária mais baixa e incentivos fiscais.

Devido a essas estratégias e à modernização de boa parte das indústrias nacionais, segundo a FIEMG (2006, p.4), algumas indústrias passaram a exportar parte de sua produção, tendo com principais mercados consumidores internacionais Estados Unidos com 35\% do total dos produtos exportados; Argentina com $28 \%$ e Uruguai com $6,08 \%$.

Diante disso, pode-se dizer que, após o setor de confecção nacional ter enfrentado uma grave crise com a abertura da economia, medidas mais consistentes vêm sendo adotadas na tentativa de melhorar a competitividade da indústria em relação aos produtos internacionais. Afinal, cada vez mais vem ocorrendo a eliminação das barreiras mercantis entre os países, tornando os mercados mais globalizados. Nesse contexto, está a eliminação do Acordo Multifibras $^{6}$ - MFA -, um dos principais acordos internacionais sobre a comercialização de têxteis e vestuários, que vigorava desde 1974, e a partir de 1994, na Rodada de negociações internacionais sobre tarifas e comércios ocorrida no Uruguai, começou a ser adaptadas às regras do GATT (Acordo Geral sobre Tarifas e Comércio). O texto final da Rodada Uruguai determinou a eliminação gradativa de todas as cotas do MFA e de outras cotas referentes a produtos têxteis. Passou a vigorar um novo acordo, o Acordo de Têxteis e Vestuário (ATV), que pode ser considerado um acordo de transição, com um período de vigência limitado. Conforme Prochnik (2002, p.15), o novo ATV objetivava liberalizar o comércio do setor têxtil e confecção em dez anos, entre 1995 a 2005. A partir daí, gradativamente, foram deixando de ter sua comercialização regulada pelo ATV e passaram a ser submetidos às regras da Organização Mundial do Comércio - OMC.

Para a ABRAVEST (2006, p.15), embora os empresários do setor tenham despendido grandes esforços para modernizar suas indústrias, após a abertura da economia ao mercado externo e a, conseqüente, crise que atingiu

6 "O Acordo Multifibras objetivava, principalmente, a contenção de exportações, através do estabelecimento de cotas e tarifas. Neste acordo, predominavam as negociações bilaterais e os países em desenvolvimento foram os mais prejudicados, pois além das restrições quantitativas, era permitido 
o setor, a grande dificuldade da maioria das micro e pequenas empresas para conseguir financiamento junto ao Banco Nacional de Desenvolvimento Econômico e Social - BNDES - fez com que muitas empresas nacionais não conseguisse alcançar a modernização necessária para se tornar suficientemente competitiva no cenário atual. Além disso, a alta carga tributária incidente sobre o setor e os elevados encargos sociais resultam numa menor competitividade dos produtos nacionais em comparação com os produtos chineses ${ }^{7}$.

\section{VANTAGENS COMPETITIVAS OFERTADAS NA REGIÃO SUDOESTE DO PARANÁ PARA O DESENVOLVIMENTO DA INDÚSTRIA DE CONFECÇÃO}

A região em Sudoeste se localiza na região Sul do Brasil e Sudoeste do Paraná. Tendo como principais fronteiras a Argentina a Oeste e ao Sul o estado de Santa Catarina. Ocupa uma área de 11.645 km², com população, em 2007, de 476.540 habitantes, e densidade demográfica de 40,92 hab/km². É composta por 37 municípios (IBGE, 2007, p.1). O mapa 01 apresenta a localização da Região em estudo dentro do Brasil e do Estado do Paraná.

As vantagens competitivas que a indústria de confecção encontra na referida região e que determinaram a implantação e o desenvolvimento da primeira nesta última, foram identificados a partir dos dados coletados em pesquisa de campo junto às indústrias de confecção, por meio de questionário de pesquisa aplicados aos proprietários desta indústria.

que os países desenvolvidos adotassem certas medidas de caráter extraordinário para defenderem os produtos nacionais" (PROCHNIK, 2002, P.14).

${ }^{7}$ Segundo a ABRAVEST (2006, p.18), o Brasil exporta o quilo de confecção a 16,17 centavos de dólar, enquanto o mesmo produto é importado da China por 4,61 centavos de dólar, ou seja, o menor custo dos produtos chineses torna a China competitiva em relação ao Brasil não só no mercado nacional, mas também no mercado externo, dificultando a comercialização dos produtos nacionais tanto no mercado interno como através de exportações para outros países. 


\section{MAPA 01 - Localização da Mesorregião Sudoeste do Paraná}

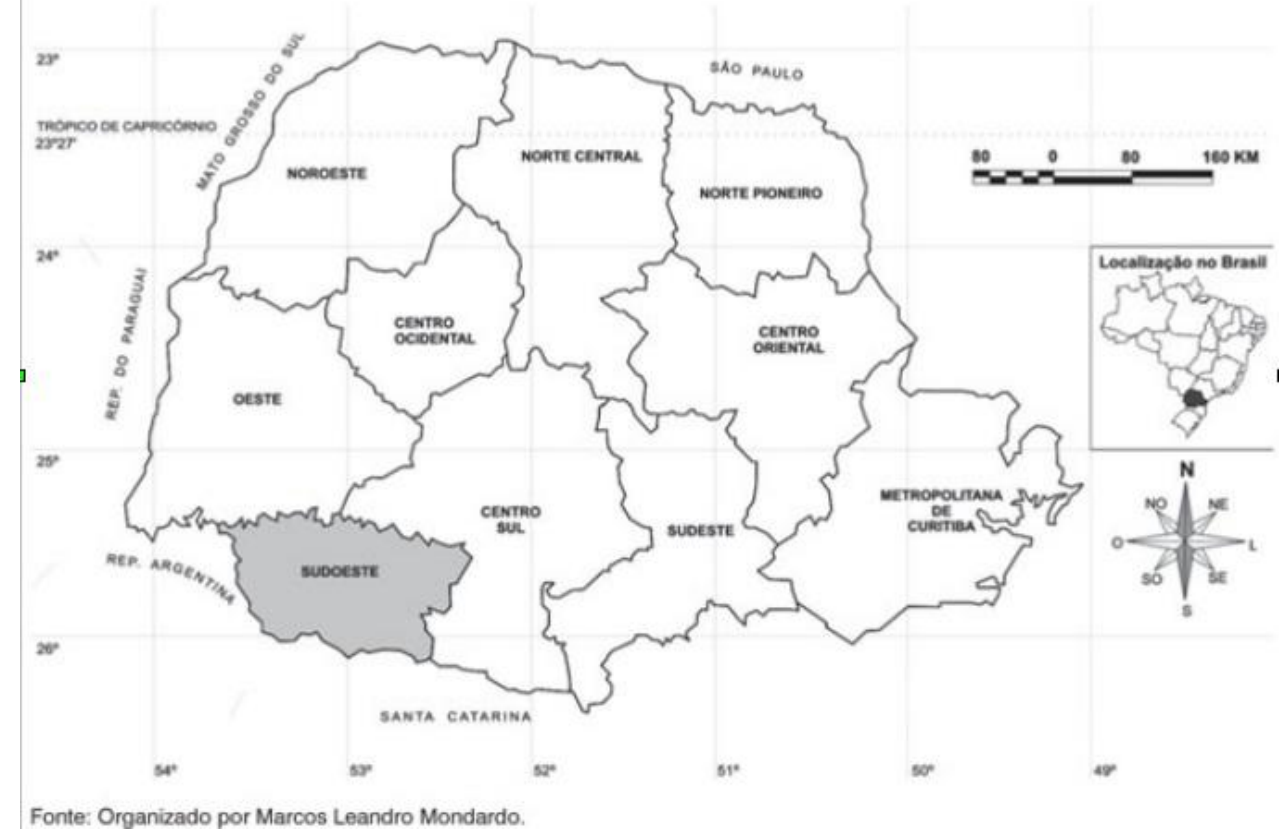

O questionário foi desenvolvido com base nas teorias sobre os condicionantes da competitividade discutidos nas seções anteriores desse artigo, levando em consideração o que os autores apontam como vantagens competitivas para a implantação e desenvolvimento da indústria em uma determinada região ou lugar, tais como: disponibilidade e custo de mão-deobra, infraestrutura e incentivos governamentais, entre outros fatores. Após a aplicação dos questionários, foram analisados e tabulados os dados.

A escolha das indústrias para aplicar o questionário, devido à grande quantidade de unidades industriais de confecção existentes na região (378 unidades), foi feita pelo seu porte, utilizando a classificação feita pelo SEBRAE, que tem como critério o número de funcionários ${ }^{8}$. As unidades industriais escolhidas para aplicar o questionário foram as de porte médio e grande. Como na região Sudoeste $0,5 \%$ das indústrias de confecção são de grande porte e $6,5 \%$ são de porte médio, das 378 indústrias existentes, 26 constituem o universo da pesquisa; são 02 de grande porte: uma com 520 funcionários e

\footnotetext{
${ }^{8}$ Segundo o SEBRAE (2006, p.18), são consideradas microempresas as indústrias que empregam até 19 funcionários; pequena empresa as indústrias que empregam de 20 a 99 funcionários; indústrias de médio porte ás que empregam de 100 a 499 funcionários e de grande porte as que empregam acima de 499 funcionários.
} 
uma com 1.150; e 24 de porte médio. O questionário foi aplicado nas 26 unidades industriais que compõem o universo da pesquisa.

Dos 37 municípios que compõem a região Sudoeste, 25 possuem unidade industrial de confecção. As primeiras unidades industriais de confecção foram implantadas na região Sudoeste no final da década de 1970 e início da década de 1980, mas somente a partir do início dos anos de 1990 o setor teve crescimento expressivo e territorializou-se pela maioria dos municípios da Região, conforme o mapa 02.

\section{MAPA 02 - Distribuição Espacial das Indústrias de Confecção dentro da Região Sudoeste do Paraná.}

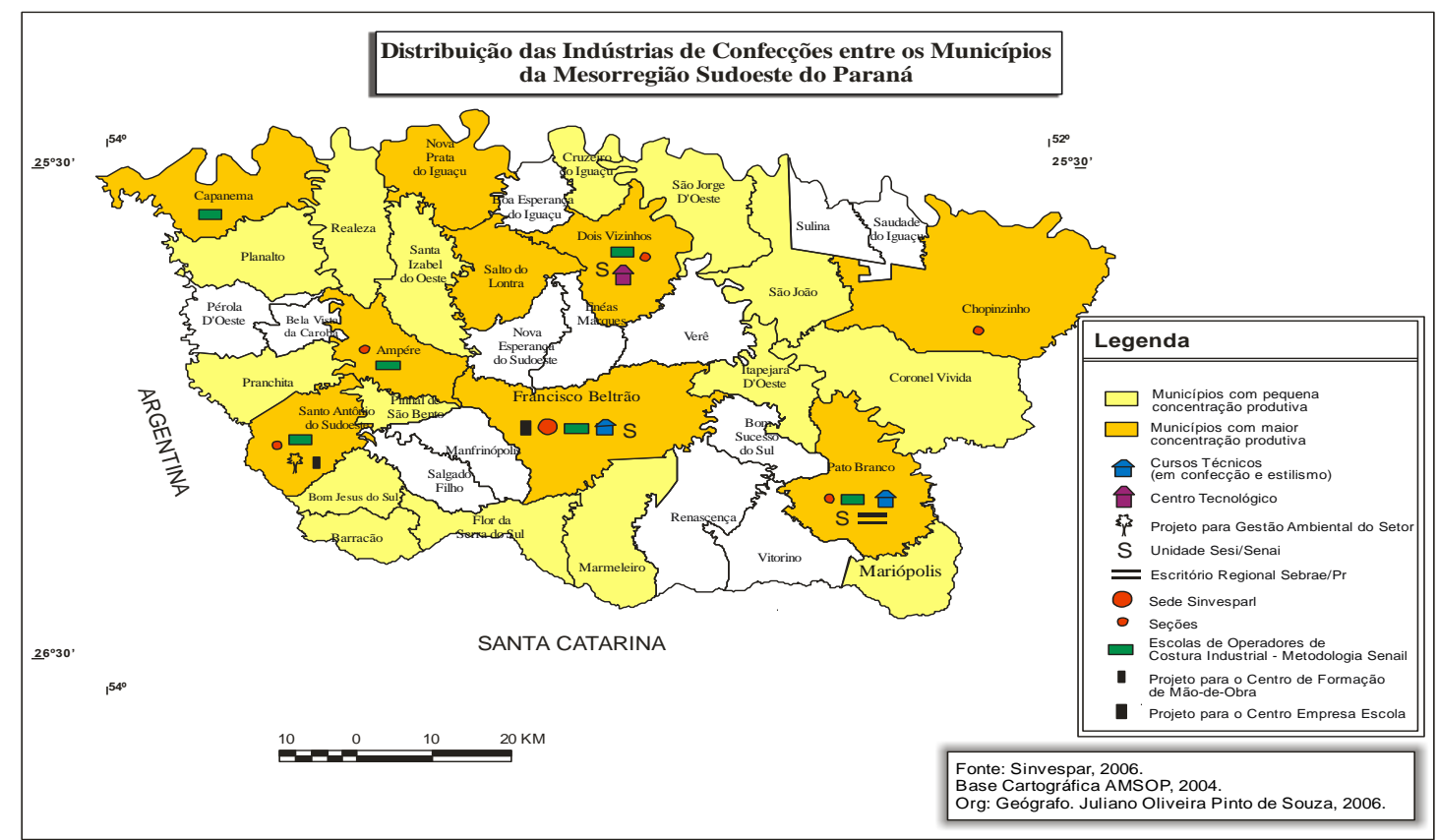

Elaboração: Juliano de Oliveira Pinto de Souza, 2006.

A indústria de confecção, por exigir pouco nível tecnológico e pequeno investimento de capital, foi uma das indústrias precursoras do processo de industrialização da região Sudoeste e se tornou um dos setores mais importantes para o desenvolvimento econômico da mesma.

O setor industrial de confecção da região Sudoeste do Paraná teve forte crescimento em número de unidades industriais nos últimos anos, 
principalmente após a década de 1990. O ritmo de evolução da indústria de confecção na Região pode ser observado através de análise das datas de implantação apresentadas no gráfico 01 , tomando como base as unidades industriais constantes na amostra.

\section{GRAFICO 01 - Período de Instalação das Indústrias de Confecção na Região Sudoeste do Paraná, total $100 \%$.}

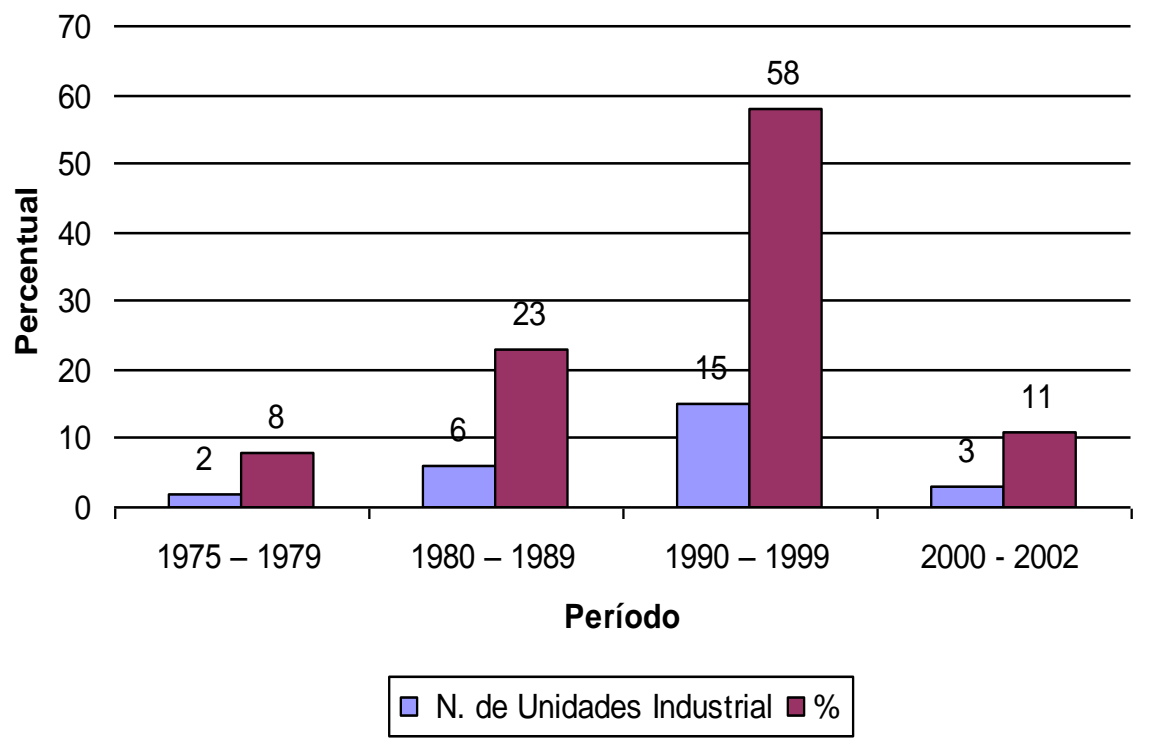

Fonte: $\square$ Pesquisa de Campo - 2007.

Entre os componentes da amostra (26) apenas 08 unidades industriais (31\%) foram implantadas entre 1975 e 1989. A grande maioria das unidades industriais (69\%) foram implantadas entre 1990 e 2002. A década de 1990 foi o período em que mais foram implantadas unidades industriais de confecção na região Sudoeste. Das 26 unidades em análise, 15 foram implantadas durante a década de 1990, e, destas, 09 unidades foram implantadas na primeira metade da década e 05 na segunda metade.

O aumento expressivo do número de unidades industriais de confecção na região Sudoeste, durante a década de 1990, está atrelado ao próprio processo de reestruturação produtiva pelo qual passou este setor em todo 0 país nesta década em função da abertura da economia ao mercado externo, conforme anunciado na seção anterior sobre a competitividade da indústria de 
confecção brasileira. Na região Sudoeste, o processo de reestruturação produtiva, induzido pela abertura comercial, fez com que as indústrias menos eficientes ou com custo de produção mais elevado falissem e, em substituição, sugiram dezenas de novas unidades industriais que, justamente, por serem novas, estavam mais adequadas ao contexto de maior competitividade e por isso sobreviveram à crise e se desenvolveram. A maioria das unidades industriais que compõem a amostra da pesquisa, quando iniciaram suas atividades, eram micro indústrias, mas, atualmente, 24 delas já alcançaram 0 porte médio e duas são de grande porte.

No total, entre os anos 1990 e 2003, segundo o Diagnóstico setorial da indústria de confecções do Sudoeste do Paraná (2004, p.03), o setor de confecção do Sudoeste teve um crescimento de 157\%, passando de 115 unidades industriais, em 1990, para 296 em 2003.

Em 2006, último diagnóstico realizado sobre o setor, o parque industrial de confecção da região Sudoeste (nos 37 municípios), segundo o SINVESPAR (2006, p.07), era composto por 378 unidades industriais, gerando aproximadamente 5.280 empregos diretos e 2.500 indiretos com uma produção estimada de 16 milhões de peças por ano.

Segundo IPARDES (2004, p.85), o setor de confecção, em 2002, era o segundo setor industrial com maior participação no VAF da indústria regional, com 7,4\% do total produzido, e, em 2003, o segundo maior gerador de postos de trabalho com uma participação de $23,5 \%$, perdendo apenas para a agroindústria.

O crescimento expressivo da indústria de confecção instalada na região Sudoeste a partir da década de 1990, que se deu tanto em número de unidades industriais como em escala de produção, ocorreu graças a um conjunto de fatores competitivos que a indústria de confecção encontrou na referida Região, conforme pode ser observado na tabela 01, que apresenta as principais vantagens competitivas encontrada na região Sudoeste pela indústria de confecção. 
TABELA 01 - Maiores Vantagens Competitivas que a Indústria de Confecção encontra na Mesorregião Sudoeste em Comparação a outras Regiões do Estado ou País.

\begin{tabular}{l|r|r}
\multicolumn{1}{c|}{ Vantagens } & $\mathbf{N}^{\circ}$ de Indústrias & $\%$ \\
\hline $\begin{array}{l}\text { Incentivos governamentais, como doação } \\
\text { de terrenos e barracão e incentivos }\end{array}$ & 13 & 26 \\
fiscais. & 10 & 20 \\
Mão-de-obra barata. & 8 & 16 \\
Mão-de-obra abundante. & 8 & 16 \\
Qualidade da infraestrutura local. & 6 & 12 \\
Mão-de-obra qualificada. & 1 & 2 \\
Proximidade com o mercado fornecedor. & 1 & 2 \\
Persistência dos empresários. & 1 & 2 \\
Criatividade. & 2 & 4 \\
Não Respondeu. & $\mathbf{5 0}$ & $\mathbf{1 0 0}$ \\
Total &
\end{tabular}

Fonte: Pesquisa de Campo - 2007

* O total de respostas é superior ao número da amostra porque o empresário poderia apresentar mais de uma resposta.

Como é possível observar na tabela 01 , os fatores competitivos encontrados na região Sudoeste do Paraná para a implantação e desenvolvimento da indústria de confecção estão diretamente relacionados aos condicionantes da vantagem competitiva das teorias de Porter e Coutinho e Ferraz, expostas na primeira seção, especialmente no que diz respeito às Condições de Fatores de Porter e aos Fatores Sistêmicos de Coutinho e Ferraz, cujos condicionantes das vantagens competitivas locais estão contemplados. Além destes, fatores internos à empresa também tiveram peso na criação da vantagem competitiva para o desenvolvimento da referida indústria como poderá ser constatado mais adiante.

Quanto às vantagens encontradas na região Sudoeste, os dados da tabela 01 revelam que os incentivos governamentais ofertados, o custo da mão-de-obra pago pelo setor e a disponibilidade de mão-de-obra apresentamse como as principais vantagens competitivas que a região Sudoeste oferece para a implantação e desenvolvimento da indústria de confecção. Outros dois fatores competitivos citados pelos entrevistados estão relacionados à organização das indústrias, ou seja, referem-se aos Fatores Internos à Empresa de Coutinho e Ferraz, que são a criatividade e a persistência dos 
empresários. Além destes, a pesquisa de campo também revelou que os empresários, a partir da década de 1990, investiram em maior capacitação tecnológica, aperfeiçoamento de recursos humanos, melhorias do produto e criação de marcas próprias, cujos fatores, que estão sob a decisão das empresas, contribuíram para o aumento da competitividade da indústria de confecção localizada no Sudoeste do Paraná.

No que se refere aos incentivos governamentais, os dados coletados na pesquisa de campo revelam que um em cada dois dos empresários entrevistados recebeu benefícios governamentais para a implantação de sua indústria na Região, principalmente doação de terrenos e barracões. Isso evidencia um estímulo por parte do setor público para a implantação de indústrias dessa natureza na Região. Além disso, a indústria de confecção do Sudoeste do Paraná está entre as que pagam os menores salários se comparada a outras regiões do Estado e do País. No primeiro semestre de 2006, enquanto o setor de confecção da região Sudoeste pagava um salário de 373 reais, o salário pago pela indústria de confecção da região Oeste do Paraná, segundo o Sindicato da Indústria de Vestuário do Oeste do Paraná SINDWEST - era de 400,89 reais, equivalendo a uma diferença de 9,3\%. Já na região Norte Central, onde se situa o APL de confecção de Maringá, o salário pago pelo setor, no mesmo período, segundo o Sindicato dos Alfaiates, Costureiras e Trabalhadores na Indústria de Confecção de Roupas de Maringá - SINCONFEMAR, era de 430 reais, ou seja, 15\% superior ao salário pago na região Sudoeste. Em relação a outros estados do País, como Santa Catarina e São Paulo, por exemplo, as diferenças salariais são ainda maiores. Em Santa Catarina, o salário pago pelo setor de confecção às costureiras, no primeiro semestre de 2006, na região de Blumenau e Brusque, segundo o Sindicato dos Trabalhadores Têxteis e Fiação de Blumenau, variava em torno 450 a 700 reais dependendo do porte da empresa. Já em São Paulo, capital, o salário pago no mesmo período, segundo o Sindicato das Costureiras de São Paulo e Osasco, era de 624,56 reais.

Embora essa diferença salarial entre as regiões e estados citados tenha sofrido uma redução significativa a partir de 2007, o custo da mão-de-obra foi 
um dos fatores que contribui significativamente para o desenvolvimento da indústria de confecção na região em análise. A consciência dos entrevistados sobre a vantagem dos salários pagos pelo setor de confecção da região Sudoeste em relação a outras regiões do Estado ou do País se reflete na avaliação feita por eles sobre o custo da mão-de-obra pago pelo setor na região apresentado na tabela 02.

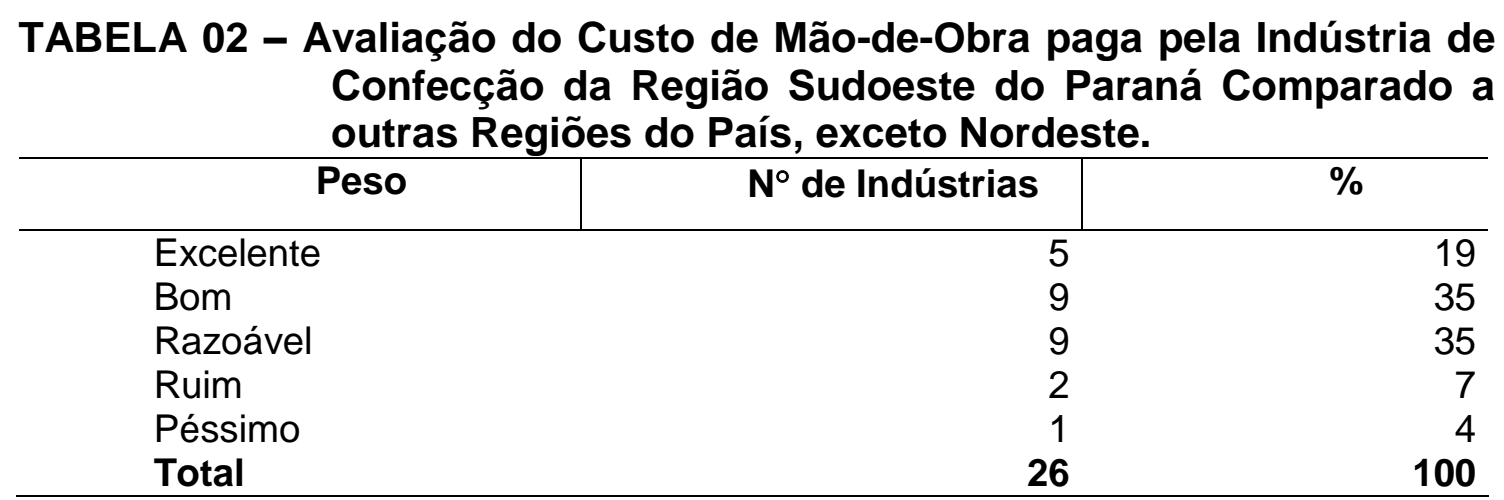

Fonte: Pesquisa de Campo - 2007

Os que consideraram o salário pago pelo setor, na Região, como excelente e bom somam $54 \%$ dos entrevistados, o que significa que a maioria dos empresários não têm problemas de competitividade por causa dos salários. A soma dos que consideraram o custo da mão-de-obra paga pelo setor, na Região, como excelente, bom e razoável chega a $89 \%$ dos entrevistados, ou seja, apenas $11 \%$ dos entrevistados avaliaram os salários pagos na região Sudoeste em comparação a outras regiões do Estado ou País, exceto o Nordeste, como ruim ou péssimo para a competitividade da indústria de confecção. Esse percentual diz respeito principalmente às indústrias que trabalham com enxovais para batizados ou noivas, as quais são ainda mais intensivas em mão-de-obra em função do bordado das peças.

Os fatores oferta e qualificação da mão-de-obra também foram citados pelos entrevistados como vantagem da região Sudoeste para 0 desenvolvimento da indústria de confecção, como foi possível observar na tabela 01 . Das 50 respostas obtidas sobre as maiores vantagens competitivas que a indústria de confecção encontra na região Sudoeste em comparação a outras regiões do Estado ou País, 16\% (08 dos 26 entrevistados) apontaram a 
abundância de oferta de mão-de-obra como uma das maiores vantagens que o setor encontra na região Sudoeste para o seu desenvolvimento e 12\% (06) das 50 respostas obtidas apontam a oferta de mão-de-obra qualificada existente como um das vantagens oferecidas pela região Sudoeste para o desenvolvimento do setor de confecção. A oferta de mão-de-obra qualificada ocorre na Região em menor nível e não privilegia todas as indústrias. O que se observou (durante a pesquisa de campo) é que a pouca mão-de-obra qualificada pelas entidades da Região, principalmente aqueles funcionários que se sobressaem durante o treinamento, são direcionados para as indústrias que têm mais "status" na Região e mais contato com os órgãos formadores da mãode-obra. Esse fato foi motivo de queixa de vários empresários durante a pesquisa. Uma avaliação mais detalhada feita pelos entrevistados, especificamente sobre a oferta e qualificação da mão-de-obra existente na Região, pode ser observada na tabela 03.

\begin{tabular}{l|r|r|r|r} 
TABELA 03 - Avaliação dos Entrevistados sobre a Oferta e Qualificação \\
da Mão-de-Obra Disponível na Região Sudoeste do Paraná \\
para a Indústria de Confecção
\end{tabular}

Fonte: Pesquisa de Campo - 2007

Pode-se observar, na tabela 03 , que há uma relação praticamente inversa quanto à mão-de-obra disponível e a mão-de-obra qualificada existente na Região. Enquanto $88 \%$ dos entrevistados avaliam a oferta de mão-de-obra existente na Região como bom e excelente, apenas $16 \%$ dos entrevistados consideraram a oferta de mão-de-obra qualificada na região Sudoeste como bom e excelente. Nenhum entrevistado avaliou a oferta de mão-de-obra existente na Região como péssimo e apenas 02 (8\%) dos 26 entrevistados 
consideraram-na como fraca. Quanto à oferta de mão-de-obra qualificada, a soma dos entrevistados que a avaliaram como fraca e péssima foi de $72 \%$, o que deixa claro a deficiência desse fator na região Sudoeste e evidencia a dificuldade enfrentada pelas indústrias para a qualificação da mão-de-obra.

Apesar da oferta de mão-de-obra qualificada (treinada) para a indústria de confecção da Região ainda ser insuficiente, a pesquisa revelou que, na região Sudoeste, há uma diversidade de estratégias usadas para qualificar a mão-de-obra, como mostra a tabela 04, evidenciando a ocorrência de uma mobilização dos empresários e do setor público da Região para aumentar a oferta de mão-de-obra qualificada e, consequentemente, tornar a indústria do Sudoeste mais competitiva, com o aproveitamento do farto recurso mão-deobra disponível na Região.

TABELA 04 - Instituições que Realizam a Qualificação (treinamento) de Mão-de-Obra para a Indústria de Confecção da Região Sudoeste do Paraná

\begin{tabular}{l|r|c}
\hline \multicolumn{1}{c|}{ Instituições } & $\begin{array}{r}\mathbf{N}^{\circ} \text { de } \\
\text { Indúst. }\end{array}$ & $\%$ \\
\hline As Próprias indústrias de confecção da região. & 14 & 26 \\
As Empresas do sistema S (Senai, Sesi, Senac, Sebrae). & 12 & 22 \\
O Setor público do município onde a indústria está instalada. & 9 & 17 \\
O Setor Público municipal em parceria com os empresários. & 7 & 13 \\
As Empresas do sistema S, SINVESPAR, e instituições & & \\
particulares de ensino (UNISEP). & 7 & 13 \\
O Sindicato das Indústrias de Confecção do Sudoeste - & 5 & 9 \\
SINVESPAR. & $\mathbf{5 4}$ & $\mathbf{1 0 0}$ \\
Total* & & \\
\hline
\end{tabular}

Fonte: Pesquisa de Campo - 2007. * O total de respostas é superior ao número da amostra porque o empresário poderia apresentar mais de uma resposta.

Do conjunto de instituições que realizam a qualificação de mão-de-obra para a indústria de confecção da região Sudoeste, as próprias indústrias de confecção são as responsáveis pela maior porcentagem. Do total de respostas, $14(26 \%)$ entre as 54 apontaram as próprias indústrias como as responsáveis pela qualificação da mão-de-obra utilizada no processo de produção. As 
indústrias que qualificam sua própria mão-de-obra, segundo os entrevistados, possuem um custo médio em torno de $1,5 \%$ do seu faturamento.

As instituições que possuem maior participação na qualificação da mãode-obra, além das próprias indústrias, são as empresas do sistema S (Senac, Senai, Sebrae, Sesi), que obtiveram 22\% das respostas; o setor público do município onde as indústrias estão instaladas foi apontado por 17\% (09) das respostas. O Sindicato das Indústrias de Confecção do Sudoeste SINVESPAR, também vem assumindo essa responsabilidade, realizando cursos de corte e costura, do básico ao avançado, foi apontado por $9 \%$ dos entrevistados como instituição atuante na qualificação da mão-de-obra para a indústria de confecção. Após a formação do Pólo da Confecção do Sudoeste, foram desenvolvidas políticas educacionais voltadas para a qualificação de mão-de-obra e, nas unidades do SINVESPAR, foram montadas escolas de corte e costura com máquinas cedidas pelos empresários do setor. Em Francisco Beltrão, onde se localiza a sede principal do SINVESPAR, existe uma parceria entre empresários e setor público, em que o Sindicato entra com as máquinas e a prefeitura paga os salários dos instrutores. O SINVESPAR também formou escolas itinerantes para aproveitar as mesmas máquinas na qualificação de mão-de-obra em vários municípios.

Outro fator que está entre os mais citados pelos entrevistados, na tabela 01, como vantagem competitiva para a indústria de confecção, na região Sudoeste, é a infraestrutura local (transporte, energia, telecomunicação). Com um percentual da importância de 16\% (08 das 50 respostas) foi apontada a infraestrutura local como uma das vantagens oferecida pela região Sudoeste para o desenvolvimento do setor. $\mathrm{Na}$ avaliação feita pelos entrevistados sobre a qualidade da infraestrutura local, tabela 05, pode-se perceber mais claramente o conceito dos entrevistados sobre a qualidade desta e entender porque aquela foi apontada por 8 dos 26 entrevistados como uma das vantagens competitivas ofertadas pela região Sudoeste para o desenvolvimento da indústria de confecção. 
TABELA 05 - Avaliação dos Entrevistados sobre a Qualidade da Infraestrutura Existente na Região Sudoeste

\begin{tabular}{l|r|r}
\hline $\begin{array}{l}\text { Qualidade da } \\
\text { Infraestrutura }\end{array}$ & $\mathbf{N}^{\circ}$ de Entrevistados & \% \\
\hline Excelente & 5 & 19 \\
Bom & 7 & 27 \\
Razoável & 8 & 31 \\
Ruim & 6 & 23 \\
Total & $\mathbf{2 6}$ & $\mathbf{1 0 0}$ \\
\hline
\end{tabular}

Fonte: Pesquisa de Campo - 2007

Os que consideram a infraestrutura da região Sudoeste excelente ou boa somam $46 \%$ dos entrevistados. Além disso, 08 dos 26 entrevistados (31\%) consideraram-na como razoável, enquanto apenas $23 \%$ avaliaram como ruim e nenhum dos entrevistados a avaliou como péssima (alternativa apresentada na questão). O conceito que os empresários do setor de confecção possuem da infraestrutura da Região justifica terem-na apontado como uma das principais vantagens da região Sudoeste para a indústria de confecção.

Em comparação com a infraestrutura que existia na Região quando as primeiras indústrias foram implantadas, os empresários do setor reconhecem que a existente, atualmente, na Região melhorou consideravelmente e em virtude de alguns dos empresários entrevistados terem vivenciado períodos difíceis com a mesma, principalmente em relação ao transporte de matériaprima, reconhecem que esse setor teve grandes avanços.

\section{CONSIDERAÇÕES FINAIS}

A competitividade sistêmica é um processo que está relacionado à capacidade das indústrias, mas que se estende à capacidade dos países e regiões e de seus cidadãos de criar condições favoráveis à competitividade. Seu significado está relacionado a um conjunto de elementos que atinge desde fatores externos à nação (como políticas internacionais com reflexos negativo ou positivo sobre determinado país) até fatores internos às próprias indústrias como, por exemplo, o controle de qualidade do produto e estratégias empresariais. No âmbito das indústrias, o conceito de competitividade está 
relacionado com um bem-sucedido desempenho no mercado em que elas concorrem.

Nesse artigo, as reflexões teóricas sobre a competitividade sistêmica, as informações empíricas e a articulação entre elas, sistematizadas, permitiram identificar fatores que condicionaram a implantação e o desenvolvimento da indústria de confecção na região Sudoeste, assim como a importância atual da indústria de confecção no desenvolvimento econômico da Região.

Os estudos sobre a competitividade sistêmica proporcionaram a identificação dos fatores que influenciam na competitividade da indústria de confecção nacional nos mais diferentes níveis (internacional, nacional e regional), e, consequentemente, os fatores que determinam a escolha da região ou local para a implantação dessa indústria.

Do mesmo modo, o estudo realizado na segunda seção sobre a competitividade da indústria de confecção nacional, em suas mais diferentes dimensões, proporcionou grande contribuição na compreensão dos determinantes da vantagem competitiva dessa indústria nas mais diferentes escalas geográficas.

Neste sentido, os estudos sobre a competitividade sistêmica possibilitaram a compreensão e identificação dos fatores que atuam sobre a competitividade da indústria de confecção na Região Sudoeste do Paraná. Com base nesse estudo foi possível identificar vantagens oferecidas pela região Sudoeste que impulsionam a implantação e desenvolvimento da indústria de confecção.

A pesquisa de campo revelou que as vantagens competitivas existentes na região Sudoeste que impulsionaram (e continuam contribuindo), para o desenvolvimento da indústria de confecção são os incentivos governamentais; o custo de mão-de-obra pago pelo setor; disponibilidade de mão-de-obra existente na Região e qualidade da infraestrutura local. Além dessas, a mãode-obra qualificada, embora em porcentagem bem menor, também foi apontada como uma vantagem competitiva que a referida indústria encontra na região Sudoeste. 
A indústria de confecção da região Sudoeste experimentou forte crescimento na década de 1990 e nos primeiros anos deste novo século. Tal crescimento the conferiu destaque na economia sudoestina, passando a responder pela segunda posição entre os setores industriais que mais geram emprego e renda.

No entanto, apesar da sua destacada posição na economia regional o setor de confecção por possuir um nível salarial muito baixo tem alcance limitado para melhorar a sociedade local. O salário base pago pela indústria a seus empregados é pouco maior que o mínimo nacional (pago aos aposentados e pensionistas), ou seja, é insuficiente para um chefe de família manter com dignidade seus dependentes e progredir social, cultural e financeiramente.

Apesar disto, o crescimento do setor de confecção na região Sudoeste, de uma forma geral, pode ser considerado um fator positivo para a economia regional. Contudo, foi possível observar durante a pesquisa que a economia industrial da região está fortemente centrada em alguns poucos segmentos, caso da indústria de confecção e da indústria alimentícia, o que pode representar risco para a economia regional, especialmente no que se refere a indústria de confecção, já que uma crise nesses setores pode desestabilizar a economia regional. Para a Região, o melhor é diversificar sua economia, pois, se um setor estiver em crise, outros mantêm o dinamismo econômico necessário para seu desenvolvimento.

\section{REFÊRENCIAS}

ABRAVEST, Associação Brasileira do Vestuário. Dados do Setor de Confecções Têxteis. São Paulo, 2006. Disponível em: $<$ http://www.abravest.org.br >. Acessado em: 28/02/2010.

COUTINHO, Luciano G.; FERRAZ, João Carlos (Coord.). Estudo da Competitividade da Indústria Brasileira: Competitividade do complexo têxtil. Campinas, 1993a. Disponível em: < http://www.mct.gov.br>. Acesso em 22/02/2010.

Estudo da Competitividade da Indústria Brasileira: Competitividade da indústria do Vestuário. Campinas, 1993b. Disponível em: <http://www.mct.gov.br>. Acesso em 22/02/2010. 
. Estudo da Competitividade da Indústria Brasileira: Relatório Final. Campinas, 1993c. Disponível em: <http://www.mct.gov.br>. Acesso em 22/02/2010.

DINIZ FILHO, L. L.; VICENTINI, Y. Teorias Espaciais Contemporâneas: o conceito de competitividade sistêmica e o paradigma da sustentabilidade ambiental. Curitiba, 2004. Disponível em: <http://www.calvados.c3sl.ufpr.br >. Acesso em 31/01/2010.

FIEMG, Federação das Indústrias do Estado de Minas Gerais. Panorama Nacional: 0 vestuário no Brasil. 2006. Disponível em: <http://www.fiemg.org.br>. Acesso em 02/07/2010.

IPARDES. Instituto Paranaense de Desenvolvimento Econômico e Social. Economia e Indústria na Mesorregião Sudoeste. Curitiba: IPARDES, 2004. Disponível em <http://www.sinvespar.com.br>. Acesso em 10/05/2010.

PORTER, Michael E. A Vantagem Competitiva das Nações. Rio de Janeiro: Campus, 1989.

PROCHNIK, Victor. Estudo da Competitividade de Cadeias Integradas no Brasil: impactos de livre comércio: Cadeia têxtil e de confecções. Campinas, 2002. Disponível em: <http://www.desevolvimento.gov.br >. Acesso em 28/06/2010.

SEBRAE. Ações e Principais Iniciativas de Apoio à Cadeia no Brasil. 2006. Disponível em: <http://www.sebrae.com.br>. Acesso em 28/06/2010.

SINVESPAR. APL Moda Masculina Sudoeste do Paraná: Plano de desenvolvimento o Arranjo Produtivo Local de Moda Masculina do Sudoeste do Paraná. 2006. Disponível em <http://www.sinvespar.com.br>. Acesso em 21/06/2010. 